\title{
Geografia: ciência e profissão
}

\section{Geography: science and profession}

\author{
Emanuel dos Santos de Oliveira \\ Mestre em Geografia pela UFBA \\ Geógrafo CREA-BA nº 051825444-5 \\ Professor de Geografia da Educação Básica na \\ Rede Pública do Estado da Bahia, Brasil \\ emanueldsoliveira@gmail.com
}

\begin{abstract}
Resumo
Este estudo objetivou analisar a relação entre a Ciência Geográfica e o exercício profissional da Geografia dando enfoque à correspondência deste com o processo formativo. Através de pesquisas bibliográfica e documental fez-se o levantamento e a leitura dos textos que abordam, orientam e/ou regulamentam a Ciência Geográfica, o processo formativo e o exercício profissional da Geografia no Brasil. Após enunciar as três profissões da Geografia, as especificidades e as correlações entre elas foram explicadas. Concluiu-se que o profissional da Geografia é definido conforme a modalidade de sua formação científica e as atividades que desempenhará. Dentre os resultados apresentados estão: um quadro comparativo das categorias profissionais da Geografia no Brasil e uma seção apresentando propostas para a superação dos seus desafios formativos e laborais.
\end{abstract}

Palavras-chave: Geógrafo; Professor; Formação; Regulamentação; Exercício profissional.

\begin{abstract}
This study aimed to analyze the relationship between Geographic Science and the professional practice of Geography, focusing on the correspondence of this with the educational process. Via bibliographic and documentary searches, research and reading were done on texts relating to the regulation of Geographic Sciences and the educational and professional practices of Geography in Brazil. After delineating the three professions in Geography, specialities and their relationships were explained. It was concluded that the Geography professional is defined according to his modality of science education and the activities he will carry out. Among the presented results is a comparative framework of categories of Geography professions in Brazil and a section presenting proposals for overcoming educational and professional challenges.
\end{abstract}

Keywords: Geographer; Teacher; Training; Regulamentation; Professional practice.

\section{INTRODUÇÃO}

A definição do exercício profissional da Geografia é, ainda, algo muito vago para grande parte da comunidade geográfica - fato verificável ao notar-se o desconhecimento das nomenclaturas profissionais da Geografia. Uma das principais causas dessa imprecisão é a resistência em se debater abertamente o tema e a relação deste com o processo formativo e com a natureza própria da Ciência Geográfica, o que contribui para a construção de uma identidade profissional frágil. 
A desqualificação gratuita ou mesmo infundada do trabalho de um colega, a vaidade e a tirania do pensamento demonstram ou o descuido ou a falta de esforço intelectual em avaliar as questões sob um prisma da totalidade e da complexidade, pondo o exercício profissional de forma frágil (LOPES, 2011).

O falso entendimento de que "bacharel em geografia" é sinônimo de "pesquisador em Geografia" e até mesmo a ineficaz discussão sobre se ambos, licenciados e bacharéis, são ou não geógrafos, atestam o tamanho desconhecimento daquilo que define os campos de atuação profissional da Geografia.

Ao se orientar a formação de um profissional, deve-se, no mínimo, saber qual é a especialidade em que esse profissional atuará, e, desse modo, dar condições para que ele execute serviços com qualidade, de modo que a sociedade possa se fortalecer ao contar com os serviços prestados por um profissional que tem uma chancela do Estado para atuar (ROSA et al., 2004).

O presente estudo tem como objetivo analisar a relação entre a Ciência Geográfica e o exercício profissional da Geografia, tendo como ponto de partida o questionamento sobre a relação existente entre o processo formativo e a práxis profissional em Geografia. A partir da enunciação de cada uma das três formas regulamentadas de exercício profissional da Geografia no Brasil, procurou-se explicar as especificidades e correlações entre as respectivas categorias profissionais, demonstrando suas áreas de atuação e atividades profissionais, seus desafios formativos e laborais, além das habilidades e competências necessárias às profissões.

Através de pesquisa bibliográfica foi possível fazer o levantamento e a leitura de livros e estudos que abordam a Ciência Geográfica, o processo formativo e a práxis profissional geográfica. Por meio de pesquisa documental foram feitos o levantamento e a leitura de leis, decretos, resoluções, diretrizes e outros documentos que orientam o processo formativo e regulamentam o exercício profissional da Geografia no Brasil.

Dentre os resultados apresentados pelo estudo estão: um quadro comparativo das categorias profissionais da Geografia no Brasil e, por fim, uma seção onde são apresentadas propostas para a superação dos desafios formativos e laborais da Geografia no país.

Acredita-se que o presente estudo traz potencial contribuição para a elucidação de dúvidas quanto ao exercício profissional, dúvidas essas que acompanham tanto graduandos quanto egressos e até mesmo pós-graduandos dos cursos de Geografia.

\section{A GEOGRAFIA ENQUANTO CIÊNCIA}

O ato de conhecer é um fator de suma importância para o homem desde os primórdios de sua espécie, por isso, ao longo da história, ele desenvolveu várias formas de conhecimento, cada uma delas ajudando-o a encontrar respostas para diferentes questões com as quais se deparou e se 
depara. Uma das formas de conhecimento desenvolvidas pelo homem é aquela a que se denomina ciência.

Pode-se definir o conhecimento científico como aquele que é produzido pela investigação científica (RODRIGUES, 2008), e que propõe uma forma sistemática, metódica e crítica de desvelar o mundo, compreendê-lo, explicá-lo e dominá-lo (LAGE, 2002). Assim, “A ciência contemporânea tem sido principalmente operativa, buscando conhecer a realidade para poder intervir na natureza" (RODRIGUES, 2008, p.11).

Para desenvolver o seu processo de investigação a ciência utiliza de diferentes métodos, conceitos, abordagens e princípios, cuja aplicação está condicionada aos seus respectivos objetos de estudo. A grande complexidade que caracteriza o mundo atual faz com que surjam variados campos do conhecimento científico, cada um se dedicando ao estudo de objetos e fenômenos específicos.

A respeito da criação de variadas áreas da ciência, Andrade (2008) aponta a inexistência de ciências estanques, com objetivos bem delimitados, mas sim a existência de uma ciência única que, para facilitar o estudo de determinadas áreas, foi dividida, um pouco arbitrariamente, em várias outras, compartimentando-se uma totalidade. Uma dessas áreas da ciência é a Geografia, a qual também apresenta certas divisões internas.

Para Andrade (2008, p.22-23) “a Geografia pode ser definida como a 'ciência que estuda as relações entre a sociedade e a natureza', ou melhor, a forma como a sociedade organiza o espaço terrestre, visando melhor explorar e dispor dos recursos da natureza". Pode-se complementar a definição deste autor com a de Sauer (2000, p.141), quando este afirma que "A geografia, como descrição explicativa da Terra, fixa sua atenção na diversidade de características da Terra e as compara a partir de sua distribuição. De algum modo é sempre uma leitura da superfície terrestre".

\footnotetext{
Ao transformar a natureza, por meio do trabalho, o homem começou a produzir alimentos, ferramentas, habitações, estradas etc., ou melhor, começou a produzir o espaço geográfico. Esse espaço produzido pelo homem apresenta-se como uma segunda natureza, uma natureza social, humanizada. Assim, há a primeira natureza, aquela que foi e é produzida sem a ação humana (rios, florestas, montanhas etc.); e a segunda natureza, aquela produzida pela ação do homem (cidades, agricultura, estradas, instrumentos de trabalho etc.) (RODRIGUES, 2008, p.129-130, grifo do autor).
}

Assim, da relação dialética sociedade-natureza (re)produz-se o espaço geográfico e, para estudá-lo e explicá-lo, a Geografia utiliza de categorias de análise nele inseridas, entre elas: paisagem, lugar, região e território, fundamentais para a análise geográfica. Todavia, o espaço geográfico é a categoria mais abrangente da Geografia (RODRIGUES, 2008). Enquanto as categorias de análise compõem o arcabouço epistemológico da Geografia, os chamados princípios geográficos (Quadro 1) baseiam o chamado raciocínio geográfico. 


Quadro 1. Princípios do raciocínio geográfico.
\begin{tabular}{|c|l|}
\hline PRINCÍPIO & \multicolumn{1}{c|}{ DESCRIÇÃO } \\
\hline Analogia & $\begin{array}{l}\text { Consiste na ideia de que os fatores e os fenômenos geográficos possuem entre si uma correlação, } \\
\text { isto é, podem ser comparados de modo a identificar-se as suas semelhanças. }\end{array}$ \\
\hline Conexão & $\begin{array}{l}\text { Consiste na ideia de que os fatores e os fenômenos geográficos possuem entre si uma interação, ou } \\
\text { seja, uma interpenetração, de modo que nenhum deles atua isoladamente. }\end{array}$ \\
\hline Diferenciação & $\begin{array}{l}\text { Derivado do princípio de analogia, consiste na ideia de que os fatores e os fenômenos geográficos } \\
\text { são diversos, contribuindo assim para a heterogeneidade do espaço geográfico. }\end{array}$ \\
\hline Dinâmica & $\begin{array}{l}\text { Consiste na ideia de que os fatores e os fenômenos geográficos estão sempre em transformação, de } \\
\text { modo que a ação ininterrupta destes provoca a perpétua reorganização do espaço geográfico. }\end{array}$ \\
\hline Distribuição & $\begin{array}{l}\text { Consiste em como os objetos e fatores geográficos estão repartidos, isto é, distribuídos no espaço } \\
\text { geográfico. }\end{array}$ \\
\hline Extensão & $\begin{array}{l}\text { Consiste em delimitar a área de ocorrência de um fator ou de um fenômeno geográfico, definindo } \\
\text { assim a área de estudo. }\end{array}$ \\
\hline Localização & $\begin{array}{l}\text { Consiste na ideia de que os fatores geográficos estão posicionados na superfície terrestre e os } \\
\text { fenômenos geográficos ocorrem numa porção desta superfície. }\end{array}$ \\
\hline
\end{tabular}

Fonte: Andrade (1998 apud RODRIGUES, 2008); Trigal et al. (2015). Organizado pelo autor (2021).

Para descrever, representar, estudar e explicar os objetos, fatores e fenômenos geográficos, a Geografia utiliza de mapas, gráficos, quadros, tabelas, fotografias aéreas, imagens de satélites, etc. Esses modelos são elaborados, analisados e/ou interpretados empregando-se os princípios do raciocínio geográfico e através deles o estudioso/profissional da Geografia consegue transmitir a sua linguagem a estudiosos/profissionais de outras áreas.

A Geografia apresenta-se como uma ciência que mobiliza o conhecimento dos métodos e dos resultados de um bom número de ciências correlacionadas (LAGE, 2002). A partir dessa mobilização, a Geografia constrói o seu arcabouço teórico-metodológico e apresenta também uma série de contribuições ${ }^{1}$ aos estudos das ciências que lhe são correlatas.

Ao mobilizar conhecimentos e métodos de várias ciências, a Geografia acaba recebendo também a influência de várias vertentes filosóficas, dentre as quais está o kantismo. As teorias de Immanuel Kant (1724-1804) serão a base do nascimento da Geografia Moderna, ao transferir-lhe como paradigmas a noção do espaço como ordem espacial, a superfície terrestre como campo da taxonomia, a comparação como método e o sistema de agrupamento taxonômico dos fenômenos por suas semelhanças e diferenças (MOREIRA, 2010).

A filosofia de Kant influenciou as concepções dos geógrafos fundadores: Alexander Von Humboldt (1769-1859) e Carl Ritter (1779-1859), este historiador e filósofo, aquele geólogo e botânico. Mesmo incorporando as contribuições de Kant, Humboldt e Ritter seguem, entretanto, trajetórias diferentes: Humboldt exprime o romantismo de J. W. Goethe (1749-1832) e a filosofia da natureza de F. G. Schelling (1775-1854), enquanto Ritter parte da noção de escala que toma emprestada de J. H. Pestalozzi (1746-1827), à qual junta o romantismo da filosofia da identidade de Schelling (MOREIRA, 2010). Tanto Humboldt quanto Ritter serão, cada um à sua maneira, influenciados pelo holismo de Kant: Humboldt expressando uma concepção panteísta que vem de

${ }^{1}$ A exemplo do surgimento e o desenvolvimento dos Sistemas de Informações Geográficas (SIG). 
sua relação com o esteticismo goethiano e a filosofia da natureza de Schelling; e Ritter expressando uma concepção teísta que vem de sua relação com a filosofia combinada de Pestalozzi e de um Schelling voltado para o teísmo (MOREIRA, 2010).

Ao estudar as relações entre a sociedade e a natureza, a Geografia tem áreas em comum com os dois grandes grupos científicos, pois, se o espaço é produzido e reproduzido pela sociedade, a Geografia tem grande aproximação com as mais diversas Ciências Sociais; se a Geografia analisa a intervenção desta sociedade na natureza, tem naturalmente a necessidade de trocar conhecimentos e experiências com as Ciências Naturais; se utiliza de técnicas modernas, divulgadas pelas ciências ditas exatas, a Geografia necessita manter contatos com as chamadas Ciências Exatas (ANDRADE, 2008).

Essa mobilização e troca de conhecimentos com variadas ciências dos dois grandes grupos científicos é que caracterizam a essência interdisciplinar ${ }^{2}$ da Geografia. Mas, se por um lado essa diversidade proporciona à Geografia desenvolver-se e dar valiosas contribuições às ciências e à sociedade, por outro, causa uma série de problemas que têm acompanhado a Geografia desde a sua institucionalização como ciência. Esta diversidade de contatos e de enfoques tem ameaçado até a própria identidade ${ }^{3}$ da Geografia, fazendo com que autores conceituados afirmem ora a dualidade da Geografia, ora até a existência não de uma, mas de diversas ciências geográficas (ANDRADE, 2008).

No tocante à afirmação da dualidade da Geografia, cabe destacar a conhecida dicotomia entre Geografia Física (estudo de fenômenos naturais) e Geografia Humana (estudo dos fenômenos sociais). Tal divisão ${ }^{4}$ resultou de muita discussão na história do pensamento geográfico a respeito do estudo do conjunto desses fenômenos. Todavia, essa separação tem sido contestada ${ }^{5}$ e julgada ultrapassada, havendo hoje quem defina a Geografia como uma ciência única, que trabalha no contexto da relação sociedade-natureza (RODRIGUES, 2008).

Para Azevedo (2005) o debate entre Geografia Física e Humana é destituído de sentido, pois, ele é apenas consequência do fato de que há uma divisão fundamental da árvore do conhecimento humano que provém de muito antes da instituição da Geografia Acadêmica.

Durante a evolução do pensamento geográfico, quando considerou-se que a divisão entre Geografia Física e Geografia Humana era insuficiente, foram surgindo novas subdivisões. A

\footnotetext{
${ }^{2}$ Essa interdisciplinaridade existe desde a institucionalização da Geografia como ciência, pois os seus pioneiros eram oriundos das mais diversas áreas científicas (botânica, geologia, história, etc.). Porém, muitos utilizam desse fato para boicotar qualquer discussão sobre se restringir o exercício profissional da Geografia - no caso para aqueles que atuam fora da Universidade - aos que obtiveram formação inicial (graduação) em Geografia.

${ }^{3}$ Essa ameaça não é apenas à identidade da Geografia enquanto ciência, mas também enquanto profissão.

${ }^{4}$ Cabe também lembrar da dicotomia entre Geografia Geral e Geografia Regional, entretanto, esta divisão se refere mais à escala adota pelos estudiosos.

${ }^{5}$ Carl Sauer (2000), já em 1956, alertava para o fato de que muitos dos que mais contribuíram para a Geografia Humana, ao menos nos primeiros anos, deram também contribuições importantes para a Geografia Física.
} 
Geografia Física subdividiu-se em áreas que nasceram da interface da Geografia com as mais diversas ciências naturais: Geomorfologia (interface com a Geologia); Hidrografia (interface com a Hidrologia); Climatologia (interface com a Meteorologia); Biogeografia (interface com a Biologia), etc. A Geografia Humana, por sua vez, subdividiu-se em campos ora próprios, ora em interface com as mais diversas ciências sociais: Geografia Política; Geografia Urbana; Geografia Agrária; Geografia da População (interface com a Demografia); Geografia Econômica (interface com a Economia); Geopolítica (interface com a Ciência Política e as Relações Internacionais); etc. Ultimamente, num esforço pela integração, muitos estudiosos têm buscado caminhos teóricometodológicos que possibilitem conexões entre as mais diversas subdivisões da Geografia e nos mais variados temas.

A Geografia se caracteriza como uma ciência cuja heterogeneidade se expressa cada vez mais à medida que novas especializações surgem motivadas pela variedade temática e pela complexidade do espaço geográfico. Conforme essas especializações se desenvolvem de maneira que os especialistas de uma não dialoguem com os especialistas de outras, tem-se como consequência aquilo que Seemann (2000) entende como a procura por uma "direção defina", de maneira que muitos graduandos acabam deixando de lado conteúdos que consideram irrelevantes para a sua vida profissional. A especialização, complementa o autor, seja necessária ou não, não deve acontecer precocemente, pois é preciso identificar os componentes comuns e essenciais de qualquer treinamento geográfico, devendo o objetivo ser a competência dentro de uma consciência mais ampla.

Uma vez estudando as relações entre a Sociedade e a Natureza, a Geografia tem um objeto muito amplo, levando a ser confundida ou a penetrar em outras ciências (ANDRADE, 2008). Disso resulta, como já mencionado, o problema da ameaça à identidade, fazendo com que $o$ estudioso/praticante da Geografia muitas vezes não mais se reconheça como membro da comunidade geográfica, nem como membro de nenhuma outra. A confusão e a penetração em outras ciências não se limitam apenas ao campo de estudo, alcançando também os campos de atuação das profissões atreladas às ciências correlatas à Geografia.

A atual complexidade apresentada pelo espaço geográfico mundial, com suas transformações cada vez mais aceleradas e com problemas - sociais (violência, falta de moradia, pouco acesso aos serviços públicos, etc.), socioeconômicos (aprofundamento da pobreza e desemprego), socioambientais (poluição e contaminação dos solos, do ar e das águas) dentre outros - cada vez mais intensos, coloca um grande desafio para as ciências de um modo geral. A Geografia, com todo o seu arcabouço teórico-metodológico e seu instrumental tecnológico, possui um grande potencial para apresentar explicações satisfatórias e, em conjunto com as demais 
ciências, propor soluções plausíveis para os problemas com os quais a população mundial tem se deparado.

A respeito do compromisso do profissional de Geografia, Rodrigues (2008, p.136) considera que “aqueles que 'fazem Geografia' têm uma missão a realizar: não somente tentar compreender o mundo, como, também buscar soluções para os diversos problemas, sejam eles sociais, sejam ambientais".

\section{A GEOGRAFIA ENQUANTO PROFISSÃO}

O exercício profissional é um dos meios através dos quais aqueles que "fazem" Geografia apresentam, de alguma forma, contribuições do pensamento geográfico à sociedade e às demais ciências, o que justifica a importância do debate sobre o exercício profissional da Geografia.

A Geografia Profissional pode ser vista como a abordagem das questões ligadas ao exercício profissional, dos processos de profissionalização e, em geral, dos problemas relacionados ao mundo do trabalho (TRIGAL et al., 2015). A Geografia Profissional se refere às atividades exercidas por aqueles com formação em Geografia que não são professores, atuando em estruturas de emprego diversificadas, nas diferentes estruturas profissionais e em atividades diversas (TRIGAL et al., 2015; BROGGIO; PHLIPPONNEAU, 2001).

Embora as concepções de Trigal et al. (2015) e Broggio e Phlipponneau (2001) não contemplem aqueles que atuam ministrando aulas na educação superior e na educação básica, não se pode esquecer que o magistério constitui um exercício profissional.

Silva (1983) defende que a definição do profissional da geografia é condição necessária para a redefinição do professor de geografia do ensino superior, pois só este, modificado, poderá formar aquele. Conforme alerta Andrade (1987), para se analisar quais são as perspectivas do profissional de Geografia no Brasil, torna-se necessário esclarecer duas questões fundamentais: 1) qual a formação do profissional de Geografia; 2) qual mercado de trabalho que oferece oportunidades ao profissional de Geografia.

Para definir os profissionais da Geografia é necessário considerar os seus respectivos campos de atuação, seu público-alvo, instituições em que atuam e a existência da legislação que regulamenta as profissões. A respeito da legislação, cabe destacar, conforme lembra Lopes (2011), que não há na comunidade geográfica brasileira uma unidade formada sobre a aceitação das leis, especialmente na parte que trata do registro profissional. Para que essa aceitação seja alcançada será necessário debater de forma madura a Geografia Profissional e chegar ao entendimento de que a regulamentação profissional não define a ciência, mas sim o exercício profissional de acordo com a modalidade de formação científica. 
A discussão do que vem a ser a qualidade de um fato ou atividade profissional é de aspecto complexo e subjetivo, entretanto, a expectativa do cliente associada as normatizações - que são fruto de consenso social - direcionam a atividade profissional para um fim qualitativo esperado, cuja qualidade se materializa na satisfação que o serviço causa ao cliente e à sociedade (ROSA et al., 2004).

Se no campo epistemológico a Geografia vive, desde a "infância", uma dicotomia entre Geografia Humana e Geografia Física (quanto à natureza dos fenômenos), e entre Geografia Geral e Geografia Regional (quanto à escala de análise), no Brasil, desenvolveu-se, no processo formativo e de profissionalização, a conhecida e desnecessária dicotomia entre licenciatura e bacharelado sendo a licenciatura a formação para atuação no ensino básico e o bacharelado a formação para atuação na área técnica.

No contexto da geografia profissional no Brasil, tem-se três profissões: o Geógrafo, o Professor de Geografia da Educação Básica e o Professor de Geografia do Ensino Superior. Essas três profissões serão discutidas a seguir.

\subsection{O Geógrafo}

Geógrafo é a denominação profissional dos habilitados em cursos de graduação em Geografia que atendem aos requisitos legais para exercício da profissão (BRASIL, 1979; BRASIL, 1980). Para poder exercer a profissão de Geógrafo, um egresso no curso de graduação em Geografia precisará ter se formado na modalidade de bacharelado e requerer o seu registro profissional junto a um Conselho Regional de Engenharia e Agronomia (CREA).

O conceito legal de Geógrafo tem sido motivo de incômodos e de resistências em se discutir o exercício profissional da Geografia: legalmente, a palavra "geógrafo" é utilizada para se referir àqueles profissionais da Geografia que atuam na Área Técnica ${ }^{6}$, isto é, àqueles que obtiveram o grau de bacharel em Geografia e adquiriram o seu registro profissional junto ao CREA, mas não àqueles que obtiveram o grau de licenciado em Geografia.

Muitos colegas da comunidade geográfica brasileira enxergam tal definição legal como: 1)uma forma de se limitar o pensamento geográfico; 2)uma tentativa do legislador de definir o que é a Geografia, e; 3)uma forma de se menosprezar os licenciados em Geografia, desconsiderando que estes também estudaram/estudam/pesquisam/“fazem” Geografia, e também dominam as categorias de análise, métodos e princípios do raciocínio geográfico.

\footnotetext{
${ }^{6}$ A Área Técnica pode ser entendida como aquele campo de atuação profissional da Geografia que se distingue da docência, e que é exercido tanto em órgãos da administração pública quanto na iniciativa privada. Neste campo de atuação o Geógrafo atua sob a concepção da chamada Geografia Aplicada, isto é, desenvolvendo atividades que possam resolver problemas em benefício da sociedade.
} 
Ao abordar esta questão conceitual Santos $(2013$, p.79) recorre à uma edição do Dicionário Aurélio e conclui que "pode-se pensar que geógrafo é o estudioso de Geografia, portanto, bacharel, licenciado, especialista, mestre ou doutor", este autor continua a sua crítica:

Persiste a ideia de que geógrafo é somente o bacharel em Geografia (perante a legislação atual isso se trata de uma verdade, não sendo o professor considerado geógrafo). Esta é uma concepção que permanece com o passar dos anos, desde o surgimento do primeiro curso de graduação em Geografia e História, quando ocorreu a dicotomia entre bacharelado e licenciatura na Geografia. A concepção de que o licenciado em Geografia é somente o professor é difundida mesmo por profissionais da Geografia, em sua maioria bacharéis que não acreditam e não veem o licenciado como geógrafo (SANTOS, 2013, p.80).

Tamanha discordância com a legislação profissional vigente estimula o uso de variadas expressões alternativas para se referir a estes dois profissionais, tais como "geógrafo-licenciado e geógrafo-bacharel", "professor-geógrafo e técnico-geógrafo", "geógrafo-docente e geógrafotécnico", etc. Tais expressões são consequência da resistência em se debater abertamente o exercício profissional e sua relação com a legislação profissional pertinente, com o processo formativo e com a natureza própria da Ciência Geográfica.

“É importante mencionar que Geógrafo é profissão e não formação, já que a formação em Geografia pode ser na modalidade bacharelado ou licenciatura" (MAGALHÃES et al., 2020, p. 213). É preciso esclarecer que o profissional da Geografia - isto é, seu campo de atuação, seu público-alvo e suas atribuições profissionais - é definido, por lei, de acordo com a modalidade de formação científica na qual o egresso se graduou. A lei não define a ciência, porém, define a profissão, baseada na ciência, nas transformações da sociedade e do mercado de trabalho.

Sobre a evolução das atribuições e competências do Geógrafo, Sampaio et al. (2017) lembram que apesar da Lei 6.664 (BRASIL, 1979) regulamentar a profissão de geógrafo somente no ano de 1979, a formação e a atuação profissional dos mesmos já se fazia presente no Brasil em períodos anteriores. Desta forma, completam os autores, a regulamentação e o reconhecimento das atribuições profissionais derivaram da estrutura dos cursos de graduação em Geografia que já atuavam no País, de suas influências históricas e das ações desenvolvidas junto à sociedade pelos profissionais formados em Geografia e em áreas correlatas.

Tal marco regulatório remete a temas como disciplinamento da profissão, perfil do profissional habilitado, sua competência e seu campo de atuação, órgão fiscalizador da profissão, registro profissional, exercício da profissão etc. (LOPES, 2011).

No âmbito de sua atuação os geógrafos exercem diferentes funções objetivando contribuir com a melhoria das condições de vida da população e do ambiente (SAMPAIO et al., 2017). Os Geógrafos atuam exercendo atividades de reconhecimentos, levantamentos, estudos e pesquisas de caráter físico-geográfico, biogeográfico, antropogeográfico e geoeconômico (BRASIL, 1979), e: 
Estudam a organização espacial por meio da interpretação e da interação dos aspectos físicos e humanos; regionalizam o território em escalas que variam do local ao global; avaliam os processos de produção do espaço, subsidiando o ordenamento territorial; participam do planejamento regional, urbano, rural, ambiental e da formulação de políticas de gestão do território; procedem estudos necessários ao estabelecimento de bases territoriais; emitem laudos e pareceres técnicos; monitoram uso e ocupação da terra, vistoriam áreas em estudo, estudam a pressão antrópica e diagnosticam impactos e tendências (BRASIL, 2010, p.343).

\section{A Lei 6.664/79 (BRASIL, 1979) e o Decreto 85.138/80 (BRASIL, 1980) que} regulamentam a profissão de Geógrafo, apresentam as atribuições profissionais a serem desempenhadas no exercício de suas funções. A partir de uma análise comparativa e compilatória da Lei 6.664/79 (BRASIL, 1979), do Decreto 85.138/80 (BRASIL, 1980), das Diretrizes Curriculares Nacionais (DCN) (BRASIL, 2001) e das Anotações de Responsabilidade Técnica (ARTs) assinadas pelos Geógrafos do Estado do Paraná no período de 2011 a 2015, Sampaio et al. (2017) agruparam as atividades desenvolvidas pelos Geógrafos em sete macro áreas (Quadro 2).

Quadro 2. Principais atividades desenvolvidas pelos Geógrafos por macro área.

\begin{tabular}{|c|c|c|}
\hline $\mathbf{N}^{\circ}$ & TIPO DE OBRA & MACRO ÁREA \\
\hline 1 & Aproveitamento/desenvolvimento/preservação de recursos naturais & \multirow{6}{*}{ Análise Ambiental } \\
\hline 2 & Equacionamento de problemas referentes a recursos naturais & \\
\hline 3 & Caracterização ecológica/etológica da paisagem geográfica & \\
\hline 4 & Interpretação de condições hidrológicas de bacias fluviais & \\
\hline 5 & Planejamento físico do terreno urbano, rural e regional & \\
\hline 6 & Elaboração de relatório de impacto no meio ambiente - RIMA & \\
\hline 7 & Assistência / Assessoria / Consultoria & Consultorias \\
\hline 8 & Desempenho Cargo/Função & Funções Administrativas \\
\hline 9 & Levantamentos topográficos & \multirow{9}{*}{ Mapeamento/Geotecnologias } \\
\hline 10 & Subdivisão de áreas & \\
\hline 11 & Reserva legal e áreas de preservação permanente & \\
\hline 12 & Unificação de áreas & \\
\hline 13 & Loteamentos & \\
\hline 14 & Locação/Demarcação de lotes e quadras & \\
\hline 15 & Levantamentos geodésicos & \\
\hline 16 & Levantamento/mapeamento referentes a problemas regionais & \\
\hline 17 & Locação de sistema de saneamento & \\
\hline 18 & Laudos, avaliações, vistorias e perícias & Perícia \\
\hline 19 & Estudo/planejamento de bases de núcleos urbanos e rurais & \multirow{9}{*}{ Planejamento territorial } \\
\hline 20 & Agricultura familiar - PRONAF & \\
\hline 21 & Delimitação/caracterização de regiões e sub-regiões & \\
\hline 22 & Estudo físico-cultural de setores geoeconômicos & \\
\hline 23 & Zoneamento geo-humano & \\
\hline 24 & Pesquisas de mercado e intercâmbio comercial & \\
\hline 25 & Estruturação de sistemas de circulação & \\
\hline 26 & Políticas de povoamento e migração interna & \\
\hline 27 & Divisão administrativa da União/estados/municípios & \\
\hline 28 & Proposição/planejamento/execução de projetos & Turismo \\
\hline
\end{tabular}

Fonte: Sampaio et al. (2017). Adaptado pelo autor (2021).

Feita uma análise atenta fica fácil observar que as macro áreas de atuação profissional do Geógrafo não são estanques, isoladas umas das outras. São compostas por atividades que requerem conhecimentos e habilidades nas variadas subdivisões da Geografia, das "geografias humanas" às 
“geografias físicas”, como também da Cartografia. Não havendo, portanto, motivos para se reforçar dicotomias no processo formativo.

Dada a sua ampla área de atuação, associada às particularidades profissionais, em conjunto a falta de uma unicidade na perspectiva da categoria, o Geógrafo carece de reconhecimento por parte da sociedade, bem como de algumas instituições e de alguns órgãos públicos, que potencializam a separação, a segregação e a fragmentação da categoria, em detrimento de outras profissões (MAGALHÃES et al., 2020). Esse prejuízo do Geógrafo em detrimento de outras profissões ocorre também no âmbito do sistema $\operatorname{CONFEA}^{7} / \mathrm{CREAs}$, sistema este que, embora tenha o papel de fiscalizar o exercício do Geógrafo, o profissional acaba tendo de enfrentar disputas com as profissões que lhes são correlatas.

Outro grande problema enfrentado pelo Geógrafo é o seu "anonimato" perante o mercado de trabalho, uma vez que ele ainda é um profissional desconhecido por grande parte da sociedade, das instituições e órgãos públicos, das empresas privadas e das entidades do Terceiro Setor. Tal "anonimato" resulta tanto da visão reducionista que se tem da Geografia como "a ciência que produz mapas" - em conjunto com a visão reducionista de que o mercado de trabalho da Geografia se resume ao ensino básico -, quanto da desarticulação da categoria profissional em se divulgar, assim como do desinteresse da Geografia Acadêmica em divulgar esta profissão para a qual ela forma alunos.

Para romper este anonimato e enfrentar as disputas com as profissões que lhes são correlatas, os geógrafos têm se organizado em agremiações denominadas Associações Profissionais de Geógrafos (APROGEO), as quais são criadas por Unidade da Federação e atuam nos respectivos CREAs, e recentemente criaram a Federação Nacional de Geógrafos (FENAGEO), que por sua vez representa a profissão a nível federal no CONFEA.

As dificuldades de inserção profissional do Geógrafo estão atreladas, também, à qualidade de sua formação inicial (graduação), a qual depende do Projeto Político Pedagógico (PPP) do seu curso de graduação, da respectiva grade curricular e da qualificação profissional dos docentes que o formam. A qualidade da formação inicial será, dentre outros fatores, de vital importância para que o Geógrafo seja preparado para competir agressivamente no mercado de trabalho com as profissões correlatas formadas com um viés mais pragmático.

Santos (2013) realizou uma pesquisa sobre a formação profissional em Geografia, na qual realizou entrevistas com egressos e professores de um curso de graduação. Durante as entrevistas realizadas, relata o autor, todos os bacharéis entrevistados ressaltaram que não tiveram uma boa formação como bacharel e pesquisador em Geografia: "Um dos fatores relatados por dois entrevistados é a deficiência na formação técnica e isso acontece, na opinião deles, porque em sua

\footnotetext{
${ }^{7}$ Conselho Federal de Engenharia e Agronomia, que agrega os Conselhos Regionais de Engenharia e Agronomia.
} 
maioria os professores que se formam bacharéis em Geografia pouco exerceram a profissão de bacharel, possuindo experiência apenas em sala de aula (SANTOS, 2013, p.106).

A inexperiência dos docentes universitários no campo de atuação do Geógrafo parece ser uma constante nos cursos de bacharelado em Geografia, sendo algo que pode ser facilmente verificado na leitura dos currículos científicos (lattes) dos docentes do curso, onde muitos (se não a maioria) sequer relatam uma única experiência profissional na Área Técnica. Como formar para o exercício de uma profissão cuja realidade profissional não se conhece?

A equívoca visão de que "bacharel em Geografia" é sinônimo de "pesquisador em Geografia" é mais um fator que contribui tanto para uma má formação de bacharel, quanto para a construção de uma identidade profissional frágil do Geógrafo. Este falso entendimento advém da noção de que o bacharelado é a modalidade que prepara o formando para a pesquisa acadêmica uma vez que, geralmente, o formando do bacharelado precisa desenvolver um Trabalho de Conclusão de Curso - tornando este um potencial candidato à pós-graduação, e ignorando que a pesquisa geográfica é apenas uma das atividades realizadas pelo Geógrafo e menosprezando o potencial científico da licenciatura em Geografia.

Outra deficiência na formação do Geógrafo é a ausência do estágio supervisionado em muitas grades curriculares de bacharelado, pois, “A não realização do estágio não propicia ao futuro profissional ter um contato direto com o meio no qual ele irá atuar futuramente e isso acaba por gerar um 'medo' de exercer sua atividade profissional, um sentimento de inaptidão para atuar no mercado de trabalho" (SANTOS, 2013, p. 109-110).

Desta forma, o enfrentamento aos desafios profissionais do Geógrafo depende de um diálogo honesto entre os profissionais, as APROGEOs, o CONFEA/CREAs e a Geografia Acadêmica.

\subsection{O Professor de Geografia da Educação Básica}

A Educação Básica é o setor que mais oferece oportunidades de trabalho aos profissionais de Geografia. Consequentemente, o Professor de Geografia da Educação Básica (PGEB) é o mais conhecido profissional da Geografia no Brasil. Assim, para compreender o ofício profissional do PGEB, é preciso antes entender a Educação Básica enquanto campo de atuação profissional.

A Lei das Diretrizes e Bases da Educação Nacional (LDB) define a Educação Básica como aquela que tem a finalidade de desenvolver o educando, assegurando-lhe a formação comum indispensável para o exercício da cidadania e fornecendo-lhe meios para progredir no trabalho e em estudos posteriores (BRASIL, 1996). A Educação Básica é um dos dois níveis da Educação Escolar (cujo o segundo nível é a Educação Superior), a qual abrange os processos formativos que se desenvolvem na vida em família, na convivência humana, no trabalho, nas instituições de ensino e 
pesquisa, nos movimentos sociais e organizações da sociedade civil e nas manifestações culturais (BRASIL, 1996).

A Educação Básica é composta por três níveis: Educação Infantil, Ensino Fundamental e Ensino Médio (BRASIL, 1996). O Professor de Geografia da Educação Básica atua nas séries finais do Ensino Fundamental (6॰ $6^{\circ}, 8^{\circ}$ e $9^{\circ}$ anos) e no Ensino Médio.

Para atuar como Professor de Geografia da Educação Básica o profissional deverá ter se graduado como licenciado em Geografia. O PGEB tem o seu trabalho regulamentado pelo Ministério da Educação e Cultura - MEC, pois a Educação é assistida por órgão próprio do Governo Federal, já que a licenciatura é a forma de licença para a docência (LOPES, 2011).

Conforme descreve a Classificação Brasileira de Ocupações (BRASIL, 2010), o PGEB atua: planejando cursos, aulas e atividades escolares; ministrando aulas teóricas e práticas em escolas da rede pública e privada; acompanhando a produção da área educacional e cultural; avaliando o processo de ensino-aprendizagem e seus resultados; registrando práticas escolares de caráter pedagógico; desenvolvendo atividades de estudo; participando das atividades educacionais e comunitárias da escola. Para o desenvolvimento das suas atividades o PGEB mobiliza um conjunto de capacidades comunicativas (BRASIL, 2010) que envolvem capacidades de natureza organizacional e interacional.

Quanto ao público-alvo, o PGEB desenvolve trabalhos com crianças, adolescentes e adultos, em comunidades com contextos culturais e sociais diversificados, em escolas e instituições de ensino federais, estaduais, municipais e privadas, ONGs etc. (BRASIL, 2010).

A prática profissional do Professor de Geografia da Educação Básica envolve, por assim dizer, duas competências de gestão: a gestão da classe e a gestão dos conteúdos. A gestão da classe está relacionada à capacidade de estabelecer uma boa relação com os alunos, de manter a disciplina destes em sala de aula e firmar contratos pedagógicos que, sem autoritarismo, proporcionem à turma o ambiente considerado mais adequado ao ensino e à aprendizagem (LOPES, 2010). A gestão dos conteúdos refere-se à tarefa de ensinar com desenvoltura e, de certo modo, fazer valorizar os conteúdos geográficos que ensina, transformando, crítica e criativamente, os diversos temas selecionados pelo currículo para serem ensinados aos alunos de maneira significativa (LOPES, 2010).

O PGEB enfrenta desafios profissionais que estão atrelados a um contexto maior que é a desvalorização social dos professores da Educação Básica, além do comum sucateamento do seu local de trabalho (especialmente no caso da Escola Pública). Em algumas atividades, o PGEB pode estar sujeito a condições especiais de trabalho, como permanência em posições desconfortáveis por períodos prolongados, exposição a ruídos e ao desgaste proveniente do uso intensivo da voz (BRASIL, 2010). 
No processo formativo, o Professor de Geografia da Educação Básica enfrenta um problema similar ao do Geógrafo: ser formado por docentes que, em suas aulas, não abordam os campos de atuação profissional da Geografia (nem a Área Técnica, nem a Educação Básica) e que não adaptam as suas aulas às necessidades de aprendizado tanto do bacharel quanto do licenciado. Como consequência, muitos PGEB acabam se formando sem saber como abordar, nas escolas, os assuntos das diferentes especializações da Ciência Geográfica.

É de concordância de todos que o principal intuito e desafio de um curso de licenciatura é proporcionar uma formação que prepare o professor para o exercício da docência em sala de aula, ou seja, um curso que forneça não só os saberes teóricos e metodológicos, mas destes juntamente com saberes didáticos, e que haja uma dialética entre [sic] esses dois campos, que prepare o futuro professor a estar apto a ensinar e fazer com que seus alunos aprendam o que lhes é ensinado. Um curso de formação deve não só formar profissionais em quantidade, mas também em qualidade, por meio de uma formação sólida e teórica que possibilite enfrentar os desafios e contradições que surgem em sua práxis (SANTOS, 2013, p. 49).

Outro desafio vivido pelo PGEB no processo formativo é a visão que a Geografia Acadêmica tem de que a licenciatura é uma modalidade inapta para a pesquisa científica, pois, "observa-se que um dos principais problemas enfrentados hoje, pelos cursos de licenciatura, referese ao tratamento dispensado por parte desses cursos aos processos de investigação" (SANTOS, 2013, p. 63). Esta visão depreciativa da licenciatura se reproduz, sobretudo, nos cursos de Geografia que ofertam tanto a licenciatura quanto o bacharelado, levando a que egressos da licenciatura reingressem como alunos do bacharelado buscando não a formação para atuar na área técnica, mas apenas visando desenvolver um trabalho de conclusão de curso (geralmente monografia), adquirindo, assim, o almejado preparo para seguir na pós-graduação.

A respeito da visão depreciativa que a Geografia Acadêmica reproduz ao olhar para a licenciatura, Azevedo (2005, p. 1362) denuncia que "O status acadêmico de formar professores é explicitamente menor daquele oriundo da dita pesquisa científica. E neste ponto não só a mídia valoriza uns como faz o desfavor de contribuir para a imagem negativa da atividade docente junto ao ensino médio e fundamental".

Além de enfrentar o baixo reconhecimento social ao seu exercício profissional, o PGEB ainda tem de lidar com a baixa valorização do seu trabalho por aqueles profissionais que deveriam estar engajados na sua formação. Azevedo (2005) observou as consequências desse desdém na formação profissional dos alunos do curso de graduação em Geografia da Universidade de São Paulo, segundo este autor: há deficiência de conteúdo básico e elementar e excesso de academicismo, e os alunos têm sido incapazes de distinguir abordagem e conteúdos adequados à faixa etária e estágio do desenvolvimento cognitivo dos alunos da Educação Básica. Porém, esta realidade pode ser identificada também em outras instituições de ensino. 
Lopes (2010) realizou uma pesquisa utilizando entrevistas semiestruturadas com docentes que possuíam entre oito e dezesseis anos de experiência efetiva em sala de aula, e constatou que:

[...] na análise de sua formação inicial, os professores reclamam, em suma e mais contundentemente, da falta de pedagogia quando cursaram as disciplinas específicas, e da falta de Geografia quando cursaram as disciplinas pedagógicas. A reflexão pedagógica nem sempre considerava a natureza do conhecimento geográfico, a matéria que seria ensinada e, por outro lado, a reflexão proporcionada pelas disciplinas de conhecimentos específicos nem sempre conseguia revelar seu sentido pedagógico, quer dizer, sua importância para a formação de não-geógrafos, para a formação mais geral de crianças e jovens e as estratégias a eles relacionadas (LOPES, 2010, p. 59).

Sobre a constatação de Lopes (2010) acima, Silva e Ramires (2007) pontuam que isso tem relação com o modelo tradicionalmente encontrado nas instituições de formação de professores, onde apenas os "conteúdos específicos" seriam tratados pelos departamentos de geografia e a “questão pedagógica” seria tratada apenas pelos departamentos de educação.

O PGEB é o profissional que proporciona à sociedade o primeiro contato com a Ciência Geográfica, apresentando-lhe os primeiros conceitos geográficos, além das primeiras análises, representações e interpretações do espaço geográfico nas escalas local, regional e global.

Os impactos de uma economia cada vez mais globalizada no cotidiano das pessoas, a intensificação das relações no espaço geográfico internacional e os conflitos dela advindos e a gravidade da questão ambiental em todo o planeta, são exemplos de temas que evidenciam a importância do ensino de Geografia para a compreensão do mundo atual (LOPES, 2010).

Para orientar os alunos a compreenderem a complexidade do mundo atual, o PGEB não deve reproduzir as dicotomias da Geografia em seu exercício profissional, pois, para desenvolver temas como a gravidade da questão ambiental, por exemplo, ele precisará relacionar conhecimentos tanto da Geografia Humana quanto da Física, e assim é/será ao desenvolver conteúdos de Geografia Regional e até mesmo de Geografia da População, por exemplo. Não existe, na Educação Básica, o professor de Geografia Física ou o professor de Geografia Humana. Existe, somente, o Professor de Geografia da Educação Básica, que precisará desenvolver conteúdos correlacionando cada uma das subáreas da Geografia.

Recentemente, a Portaria $\mathrm{n}^{\circ} 1.570 / 2017$ (BRASIL, 2017) instituiu a Base Nacional Comum Curricular - BNCC, a qual estrutura o currículo da Educação Básica em Áreas do Conhecimento, sendo: Linguagens, Matemática, Ciências da Natureza, Ciências Humanas, e Ensino Religioso, no caso do Ensino Fundamental - Anos Finais; Linguagens e Suas Tecnologias, Matemática e Suas Tecnologias, Ciências da Natureza e Suas Tecnologias, Ciências Humanas e Sociais Aplicadas, no caso do Ensino Médio (BRASIL, 2018).

No caso do Ensino Fundamental - Anos Finais, as disciplinas constituem-se em componentes curriculares e o componente curricular Geografia passa a compor, junto com História, 
a área do conhecimento Ciências Humanas. Já no Ensino Médio, a Geografia - junto com Filosofia, História e Sociologia - passa a integrar a área de Ciências Humanas e Sociais Aplicadas. Entretanto, enquanto no Ensino Fundamental - Anos Finais cada disciplina constitui um componente curricular específico (com suas habilidades e competências ${ }^{8}$ específicas) e em articulação com os demais, no Ensino Médio as disciplinas aparecem “diluídas” na área de Ciências Humanas e Sociais Aplicadas, com as habilidades e competências agora sendo especificadas apenas por área e não por componente curricular.

A BNCC coloca para o PGEB novos desafios a serem enfrentados nas relações interdisciplinares, pluridisciplinares, e, principalmente transdisciplinares, havendo, portanto, que se preocupar ainda mais com o que toca a sua identidade profissional.

\subsection{O Professor de Geografia do Ensino Superior}

O terceiro e último profissional da Geografia que se faz necessário definir e discutir é o Professor de Geografia do Ensino Superior (PGES). O PGES atua desenvolvendo atividades universitárias, as quais se referem, como já mencionado, à chamada Geografia Acadêmica. Para bem discutir o papel e o exercício profissionais do Professor de Geografia do Ensino Superior é necessário, antes, entender o seu campo de atuação: a Educação Superior.

A Lei de Diretrizes e Bases da Educação Nacional (BRASIL, 1996) define a Educação Superior como aquela que é ministrada em instituições de ensino superior, e estabelece as suas finalidades, dentre estas: a)estimular o desenvolvimento do espírito científico e do pensamento reflexivo; b)formar diplomados nas diferentes áreas de conhecimento, aptos para a inserção em setores profissionais; c)incentivar a pesquisa e a investigação científica; d)promover a divulgação de conhecimentos culturais, científicos e técnicos e comunicar o saber através do ensino; e)atuar para a universalização e o aprimoramento da Educação Básica, mediante a formação e a capacitação de profissionais, a realização de pesquisas pedagógicas e o desenvolvimento de atividades de extensão que aproximem os dois níveis escolares.

O exercício das ocupações do PGES requer ensino superior completo e títulos de pósgraduação que, nem sempre, são na área de Geografia, podendo ser, portanto, em áreas correlatas à Ciência Geográfica. Aqui tem-se o exemplo do célebre professor Milton Santos, um cientista cuja formação inicial (entenda-se graduação) foi no Direito e somente mais tarde enveredou-se pela Geografia, dando reconhecidas contribuições ao pensamento geográfico.

\footnotetext{
${ }^{8} \mathrm{Na}$ BNCC define-se competência como a mobilização de conhecimentos (conceitos e procedimentos), habilidades (práticas cognitivas e socioemocionais), atitudes e valores para resolver demandas complexas do cotidiano, do pleno exercício da cidadania e do mundo do trabalho (BRASIL, 2018).
} 
Essa característica própria da Universidade, onde um docente pode lecionar num curso diferente daquele em que se formou, aliada à gênese da própria Geografia (tanto os sistematizadores quanto os primeiros teóricos da Geografia tinham formação em diferentes áreas) e exemplificada pela trajetória do professor Milton Santos, tem sido motivo de repúdio, por parte da comunidade geográfica brasileira, à tentativa de se restringir o exercício da profissão de geógrafo, isto é, a obtenção do registro de Geógrafo no CREA, aos bacharéis em Geografia ${ }^{9}$.

Trata-se de uma atitude que revela o desconhecimento das especificidades de ambos os campos de atuação profissional da Geografia, principalmente da Área Técnica. A mobilidade que tem o PGES de lecionar disciplinas em cursos e departamentos que não os de Geografia não se aplica ao Geógrafo. Portanto, a restrição que se procura é para o exercício profissional na Área Técnica, não na Acadêmica. Todo e qualquer professor do ensino superior que queira contribuir para a evolução e (re)produção do pensamento geográfico poderá fazê-lo, seja atuando ou não nos departamentos de Geografia das universidades brasileiras. Restringir o exercício do Geógrafo aos bacharéis em Geografia é valorizar a formação e a profissão ${ }^{10}$.

Cabe destacar, mais uma vez, que a lei não define a ciência, mas sim a profissão, e que, o profissional da Geografia é definido, por lei, levando-se em consideração o campo de atuação e o seu público-alvo. A Geografia Acadêmica e a Área Técnica são campos de atuação distintos, com públicos e objetivos distintos, que se interconectam no processo formativo.

O PGES atua preparando e ministrando aulas, orientando trabalhos acadêmicos, elaborando planos de ensino, supervisionando estágio, avaliando processos de ensino-aprendizagem, participando de processos de seleção e avaliação, prestando assessoria técnico-científica, exercendo atividades acadêmico-administrativas, construindo projetos político-pedagógicos e, eventualmente, desenvolvendo atividades de pesquisa e extensão (BRASIL, 2010). O exercício do trabalho pode se dar de forma presencial e à distância, e o PGES pode estar sujeito à situação de estresse, devido a trabalhos sob pressão (BRASIL, 2010).

\footnotetext{
${ }^{9}$ Cabe aqui destacar que a Lei $n^{\circ} 7.399 / 1985$ (BRASIL, 1985) junto com o seu decreto regulamentador $n^{\circ} 92.290 / 1986$ (BRASIL, 1986), alterou a redação da Lei n 6.664/1979 (BRASIL, 1979) que disciplina a profissão de Geógrafo, e possibilitou que o exercício dessa profissão seja permitido aos portadores de títulos de Mestre e Doutor em Geografia que não tenham a Geografia como formação inicial. Entretanto, não há qualquer dispositivo legal que possibilite ao Geógrafo, seja ele mestre ou doutor, obter a permissão para exercer outra profissão, seja em área correlata à Geografia ou não.

${ }^{10}$ Encontra-se em tramitação no Senado Federal (SF) o Projeto de Lei do Senado n ${ }^{\circ} 117 / 2004$, de autoria do Senador Sibá Machado (PT/AC), cujo objeto é revogar a Lei $\mathrm{n}^{\circ} 7.399 / 1985$ e o seu decreto regulamentador (92.290/86). A matéria foi aprovada em caráter terminativo na Comissão de Assuntos Sociais do SF em 1\%/12/2005, seguindo para a Câmara de Deputados em 27/03/2006 (Subsecretaria de Expediente). Em 31/10/2019 foi aprovado um texto substitutivo pela Comissão de Constituição e Justiça da Câmara dos Deputados e o Projeto de Lei retornou ao Senado para análise.
} 
O Professor de Geografia do Ensino Superior tem como missão a formação científica e profissional do Professor de Geografia da Educação Básica (antes licenciado) e do Geógrafo (antes bacharel). Formação essa que se dá, dentre outras formas, por meio do currículo.

Conforme o Art. $2^{\circ}$ da Resolução CNE/CES 14 (BRASIL, 2002), que estabelece as Diretrizes Curriculares para os cursos de Geografia, o Projeto Político-Pedagógico (PPP) de formação acadêmica e profissional oferecido pelo curso de Geografia deverá explicitar:
a) o perfil dos formandos nas modalidades bacharelado, licenciatura e profissionalizante;
b) as competências e habilidades - gerais e específicas a serem desenvolvidas;
c) a estrutura do curso;
d) os conteúdos básicos e complementares e respectivos núcleos;
e) os conteúdos definidos para a Educação Básica, no caso das licenciaturas;
f) o formato dos estágios;
g) as características das atividades complementares;
h) as formas de avaliação.

Para que o PPP defina corretamente o perfil dos formandos, é necessário que os docentes do curso conheçam a realidade profissional dos Geógrafos e dos PGEB, que entendam as habilidades e competências que estes necessitam desenvolver e executar, pois, só assim será possível estruturar o curso de maneira satisfatória, definindo os conteúdos, o formato dos estágios e as formas de avaliação pertinentes.

Conforme mencionado anteriormente, uma das deficiências de muitos bacharelados em Geografia é a inexistência do estágio supervisionado obrigatório em sua estrutura curricular, o que contribui para que haja uma insegurança no exercício profissional do futuro Geógrafo. Compreendendo a importância do estágio supervisionado, Heidrich e Verdum (2001), docentes universitários, construíram, na disciplina de Estágio Profissional do Curso de Geografia da Universidade Federal do Rio Grande do Sul, a partir do ano de 1999, uma rede de relações com instituições públicas e privadas cujas referências para a constituição iniciaram por locais onde já havia se consolidado o trabalho do Geógrafo e por instituições capazes de acolher e potencializar as capacidades dos acadêmicos estagiários, como uma estratégia de construir o reconhecimento da importância do profissional Geógrafo no conjunto da instituição. Neste processo de construção, não só criavam a vaga para a realização do estágio, mas, também, o (re)conhecimento das potencialidades desse profissional (HEIDRICH; VERDUM, 2001; VERDUM, 2007).

Dando continuidade aos trabalhos de Heidrich e Verdum (2001), Verdum (2007) avalia que o papel do professor da disciplina é importante na relação que deve ser estabelecida entre a instituição universitária e aquelas instituições em que o estágio será realizado. O professor, como representante da instituição universitária, deve compreender e exercer o seu papel com relação a sua importância na abertura e na ampliação das possibilidades que são, inclusive, vislumbradas pelos 
próprios alunos como potencialmente interessantes para o desenvolvimento de suas atividades como futuros profissionais (VERDUM, 2007).

Sobre a construção do currículo dos cursos de Geografia, Santos (2013) observou um sério problema que envolve o trabalho do PGES e que prejudica formação dos egressos:

\begin{abstract}
A estrutura curricular é vista pelos professores como um território a ser conquistado, quanto mais disciplinas voltadas para sua área de pesquisa, mais território aquele professor conquistou, detendo o poder, o que controla mais disciplinas. Dessa forma, esses professores retiram a legitimidade do PPP, deixando este de ser um instrumento planejador e norteador do curso de graduação (SANTOS, 2013, p. 81).
\end{abstract}

Essa disputa de egos e, por vezes político-ideológica, compromete o processo formativo e prejudica ainda mais a construção de uma identidade profissional do Geógrafo e do PGEB. Ou seja, não bastassem as constantes dicotomias da Geografia nos campos teórico e formativo, acrescenta-se o problema das disputas políticas docentes.

A disputa política docente é empreendida por PGES que enxergam a Geografia apenas no âmbito acadêmico, que não visualizam uma Geografia além dos muros da Universidade. A esses cabe lembrar que a Acadêmica é uma outra Geografia, nascida da necessidade de estender a educação escolar à toda população e que a maioria esmagadora dos egressos dos cursos de Geografia não constituirá um corpo de pesquisadores científicos (AZEVEDO, 2005).

Mas, se a maioria dos egressos dos cursos de Geografia não se tornará pesquisadores científicos, então, qual o papel da pesquisa científica no processo formativo de Geógrafos e de Professores de Geografia da Educação Básica? Silva e Ramires (2008) consideram que a pesquisa científica é o meio para a construção da identidade formativa tanto do Geógrafo, quanto do PGEB, pois, continuam os autores, é nos diferentes processos de pesquisa em que ambos se especificam, uma vez que os campos de trabalho de um e de outro implicam em também distintos modos de se apropriar e de aplicar o conhecimento geográfico.

Quando feitos de maneira formal e em espaços institucionais oficiais, os aportes da Geografia às demais ciências e à sociedade, a orientação do processo formativo ou mesmo a própria (re)produção do pensamento geográfico, enfim, o "fazer Geografia", constituem, em si, um exercício profissional. Assim, uma vez que as atividades da Geografia Acadêmica são uma prática profissional, é de grande importância o debate universitário sobre o exercício profissional da Geografia, inclusive, o do Professor de Geografia do Ensino Superior.

\title{
4. QUADRO COMPARATIVO DAS TRÊS PROFISSÕES DE GEOGRAFIA
}

Uma vez explicados os campos de atuação das profissões de Geografia é possível apresentar um quadro comparativo com o resumo das suas atividades desenvolvidas e seus respectivos produtos entregues (Quadro 3). 
Quadro 3. Quadro comparativo das três profissões de Geografia.

\begin{tabular}{|c|c|c|c|c|}
\hline PROFISSÃO & $\begin{array}{c}\text { ÁREA DE } \\
\text { ATUAÇÃO }\end{array}$ & $\begin{array}{l}\text { FORMAÇÃO } \\
\text { NECESSÁRIA }\end{array}$ & ATIVIDADES DESENVOLVIDAS & $\begin{array}{c}\text { PRODUTOS } \\
\text { ENTREGUES }\end{array}$ \\
\hline Geógrafo & $\begin{array}{l}\text { Área } \\
\text { Técnica }\end{array}$ & $\begin{array}{c}\text { Bacharelado em } \\
\text { Geografia }\end{array}$ & $\begin{array}{l}\text { - Análises Ambientais; } \\
\text { - Consultorias; } \\
\text { - Funções Administrativas; } \\
\text { - Mapeamentos; } \\
\text { - Perícias; } \\
\text { - Planejamento territorial; } \\
\text { - Turismo; } \\
\text { - Etc. }\end{array}$ & $\begin{array}{l}\text { - Planos de manejo; } \\
\text { - Bancos de dados } \\
\text { geoespaciais; } \\
\text { - Estudos diversos; } \\
\text { - Mapas diversos; } \\
\text { - Relatórios; } \\
\text { - Laudos; } \\
\text { - Levantamentos; } \\
\text { - Dados geoespaciais; } \\
\text { - Zoneamentos; } \\
\text { - Planos turísticos; } \\
\text { - Etc. }\end{array}$ \\
\hline $\begin{array}{l}\text { Professor de } \\
\text { Geografia da } \\
\text { Educação } \\
\text { Básica }\end{array}$ & $\begin{array}{l}\text { Educação } \\
\text { Básica }\end{array}$ & $\begin{array}{c}\text { Licenciatura em } \\
\text { Geografia }\end{array}$ & $\begin{array}{l}\text { Planejamento de cursos, aulas e } \\
\text { atividades escolares; } \\
\text { - Avaliação do processo de ensino- } \\
\text { aprendizagem e seus resultados; } \\
\text { - Registro de práticas escolares de } \\
\text { caráter pedagógico; } \\
\text { - Desenvolvimento de atividades de } \\
\text { estudo; } \\
\text { - Participação em atividades } \\
\text { educacionais e comunitárias da } \\
\text { escola. }\end{array}$ & $\begin{array}{l}\text { - Planos de cursos e } \\
\text { aulas; } \\
\text { - Registros de } \\
\text { avaliações do } \\
\text { processo de ensino- } \\
\text { aprendizagem e } \\
\text { seus resultados; } \\
\text { - Registro de práticas } \\
\text { escolares de caráter } \\
\text { pedagógico; } \\
\text { - Etc. }\end{array}$ \\
\hline $\begin{array}{l}\text { Professor de } \\
\text { Geografia do } \\
\text { Ensino } \\
\text { Superior }\end{array}$ & $\begin{array}{l}\text { Educação } \\
\text { Superior }\end{array}$ & $\begin{array}{l}\text { Graduação em } \\
\text { qualquer área } \\
\text { seguida de pós- } \\
\text { graduações. }\end{array}$ & $\begin{array}{l}\text { - Preparação e ministração de aulas; } \\
\text { - Orientação de trabalhos } \\
\text { acadêmicos; } \\
\text { - Elaboração de planos de ensino; } \\
\text { - Supervisão de estágio; } \\
\text { - Avaliação de processos de ensino- } \\
\text { aprendizagem; } \\
\text { - Participação em processos de } \\
\text { - seleção e avaliação; } \\
\text { - Assessoria técnico-científica; } \\
\text { - Atividades acadêmico- } \\
\text { administrativas; } \\
\text { - Construção de projetos político- } \\
\text { pedagógicos; } \\
\text { - Atividades de pesquisa e extensão. }\end{array}$ & $\begin{array}{l}\text { - Aulas; } \\
\text { - Trabalhos } \\
\text { acadêmicos; } \\
\text { - Planos de ensino; } \\
\text { - Relatórios técnico- } \\
\text { científicos; } \\
\text { - Projetos político- } \\
\text { pedagógicos; } \\
\text { - Etc. }\end{array}$ \\
\hline
\end{tabular}

Fonte: Brasil (1979; 2010); Sampaio et al. (2017). Organizado pelo autor (2021).

Como é possível observar no quadro comparativo das três profissões de Geografia, o Geógrafo, o PGEB e o PGES atuam em campos específicos, com públicos específicos e entregando, no geral, produtos específicos.

\section{PROPOSTAS PARA SE SUPERAR OS DESAFIOS PROFISSIONAIS DA GEOGRAFIA}

Uma vez problematizados os principais desafios formativos e laborais dos profissionais da Geografia é possível propor ações viáveis para a superação de tais reptos. 
Os desafios formativos do Geógrafo estão relacionados à ausência de estágio supervisionado no currículo, ao viés da pesquisa científica, à inexperiência dos PGES na Área Técnica, à falta de pragmatismo no curso, à falta de engajamento discente e à persistente dicotomia teórica.

É necessário que os Projetos Político-Pedagógicos dos cursos de bacharelado em Geografia estabeleçam o estágio curricular obrigatório, sendo que, para a realização do estágio curricular obrigatório é importante que os Departamentos de Geografia busquem parcerias com entidades do terceiro setor, com empresas privadas, com órgãos, entidades e empresas públicas que desenvolvam atividades relacionadas às atribuições profissionais do Geógrafo.

A pesquisa científica desenvolvida pelos bacharelandos em Geografia precisará estar relacionada, também, ao campo de atuação profissional do Geógrafo, contemplando cada uma das macro áreas de atividades profissionais na Área Técnica.

A inexperiência profissional dos PGES na Área Técnica é um problema que precisa ser urgentemente solucionado. Inclusive, deve-se considerar, para o longo prazo, a exigência de comprovação de experiência profissional como Geógrafo para se exercer a docência universitária em Geografia.

A falta de pragmatismo no curso de bacharelado em Geografia precisa ser preenchida justamente com um enfoque pragmático no processo formativo. Não se propõe aqui a extinção das reflexões críticas, mas sim a inserção do viés pragmático combinando-o à reflexão crítica, pois, somente essa combinação preparará o futuro Geógrafo para uma atuação profissional socialmente engajada e ao mesmo tempo agressiva para competir com outros profissionais que atuam em áreas correlatas a sua.

O corpo discente dos cursos de bacharelado e, principalmente, a representação estudantil deverão estar engajados em discutir o seu futuro exercício profissional e em cobrar mudanças que proporcionem melhor qualificação do processo formativo. É importante considerar atividades de extensão voltadas ao mundo do trabalho, tais como empresas juniores ${ }^{11}$, startups e incubadoras de empresas.

Os desafios laborais do Geógrafo estão relacionados ao anonimato da categoria, à insegurança na práxis profissional, à concorrência com profissões correlatas e à representatividade no sistema CONFEA/CREAs.

\footnotetext{
${ }^{11}$ Empresas Juniores (EJs) são entidades jurídicas sem fins lucrativos administradas por estudantes de graduação sob a orientação de um docente do curso. Através de uma EJ os graduandos desenvolvem habilidades de gestão empresarial, prestam serviços atrelados a sua futura profissão e são inseridos no mundo do trabalho. A criação de Empresas Juniores pode ampliar as chances de empregabilidade dos recém-graduados em Geografia (OLIVEIRA et al, 2015), contribuindo consideravelmente para a formação profissional do Geógrafo (BONFIGLIO, 2006).
} 
A superação do anonimato do Geógrafo depende de maior divulgação do profissional e suas potencialidades, de maior representatividade perante a sociedade, os órgãos públicos e as empresas privadas. Porém, tudo isso dependerá de ações coordenadas entre as APROGEOs, a FENAGEO, a Geografia Acadêmica e a Associação dos Geógrafos Brasileiros (AGB).

Para vencer a insegurança na sua práxis, o Geógrafo precisará - à parte a superação dos desafios formativos - fortalecer a sua identidade profissional. Para isso, ele deverá refletir sobre o seu percurso formativo para, então, reconhecer o potencial da sua fundamentação teóricometodológica para realizar bons serviços e propor soluções técnicas viáveis.

Para se destacar na concorrência com profissões correlatas, o Geógrafo precisará vencer a insegurança na sua práxis e fortalecer a sua identidade profissional. Somente assim, estará pronto para mostrar o porquê de ser melhor que outras profissões no desempenho de determinadas atividades, bem como conseguirá provar que tem relevância para compor equipes multidisciplinares em trabalhos multi e interdisciplinares.

Para melhorar o quadro da sua representatividade no sistema CONFEA/CREAs, os Geógrafos precisam se articular melhor para fortalecer as suas entidades representativas: as APROGEOs e a FENAGEO. Além disso, vale lembrar que também as Universidades têm representatividade no conselho profissional, logo, os Departamentos de Geografia devem entrar na disputa com outros cursos das suas respectivas instituições para poder representar a Universidade, sendo, assim, mais uma forma de a Geografia se fazer representada nos CREAs.

Quanto às dicotomias teóricas, é clara a inexistência, na Área Técnica, do Geógrafo Humano e do Geógrafo Físico, mas apenas a existência do Geógrafo. O campo de atuação profissional do Geógrafo não dá margens para dicotomias teóricas, logo, a formação deve ser conduzida à via da integração e da convergência entre as divisões e subdivisões da Geografia.

Os desafios formativos do Professor de Geografia da Educação Básica estão relacionados: à falta de geografia nas disciplinas pedagógicas; à falta de pedagogia nas disciplinas geográficas; ao viés da pesquisa científica; à falta de engajamento discente; à desvalorização da licenciatura pelos docentes do curso; e à persistente dicotomia teórica.

A falta de geografia nas disciplinas pedagógicas pode ser enfrentada abordando-se o trabalho com os conteúdos de Geografia na Educação Básica, de modo a identificar quais habilidades pedagógicas e recursos didáticos são necessários à essa tarefa. Para isso, contudo, será necessário um diálogo entre os Departamentos de Geografia e as Faculdades de Educação.

A falta de pedagogia nas disciplinas geográficas pode ser superada estudando-se a maneira como os conteúdos geográficos (Geomorfologia, Climatologia, Biogeografia, Geografia Urbana, Geografia da População, Geografia Econômica, etc.) são abordados pelos livros didáticos, e como estes conteúdos são e/ou podem ser trabalhados na Educação Básica. 
A pesquisa científica desenvolvida pelos licenciandos em Geografia precisará estar relacionada, também, ao campo de atuação profissional do Professor de Geografia da Educação Básica, contemplando temas e desafios laborais da e na Educação Básica.

O corpo discente dos cursos de licenciatura e a sua representação estudantil deverão engajar-se em discutir o seu futuro exercício profissional e em cobrar mudanças que proporcionem melhor qualificação e valorização do processo formativo em todos os aspectos. Tal articulação será necessária, inclusive, para que se possa enfrentar a desvalorização da licenciatura pelos próprios docentes do curso.

Quanto à persistência das dicotomias teóricas, está claro que não existem o PGEB de Geografia Humana e nem o PGEB de Geografia Física, mas apenas o Professor de Geografia da Educação Básica. A Educação Básica é, portanto, um campo de atuação profissional que não dá margens para dicotomias teóricas, logo, o processo formativo do licenciado precisa ser conduzido à via da integração e da convergência entre as divisões e subdivisões da Geografia.

Os desafios laborais do Professor de Geografia da Educação Básica estão relacionados à desvalorização social da profissão, à gestão da classe e à gestão dos conteúdos.

$\mathrm{O}$ enfrentamento à desvalorização social do PGEB depende do combate à desvalorização dos professores da Educação Básica, não sendo o bastante, portanto, discutir a valorização dele apenas entre a comunidade geográfica. Entretanto, um esforço que pode e deve ser feito é no sentido de se fortalecer e engrandecer a Geografia enquanto componente curricular da Educação Básica.

A gestão da classe é um objetivo que, para ser alcançado, depende do emprego de habilidades organizacionais e interativas que precisam ser desenvolvidas durante o processo formativo, tanto nas aulas das disciplinas pedagógicas, quanto nas disciplinas geográficas.

A gestão dos conteúdos é um objetivo que depende da habilidade do PGEB em despertar nos alunos o interesse pelos conteúdos e temáticas do pensamento geográfico. Tal habilidade deve ser desenvolvida no processo formativo.

As propostas aqui apresentadas partem do princípio de que é necessário à comunidade geográfica abandonar dicotomias teóricas, perceber que as especializações da Geografia não coincidem com os campos de atuação profissional, e compreender que a legislação não define a ciência, mas sim a profissão, de acordo com a modalidade de formação científica. Portanto, é necessário avaliar o processo formativo para qualificar o exercício profissional, e estudar o exercício profissional para, assim, reestruturar o processo formativo e ressignificar a práxis profissional do Professor de Geografia do Ensino Superior. 


\section{CONSIDERAÇÕES FINAIS}

A definição do exercício profissional da Geografia é, ainda, algo muito vago para grande parte da comunidade geográfica brasileira - fato verificável ao notar-se o desconhecimento das nomenclaturas profissionais da Geografia. Uma das principais causas dessa imprecisão é a resistência em se debater abertamente o tema e a relação deste com o processo formativo e com a natureza própria da Ciência Geográfica, o que contribui para a construção de uma identidade profissional frágil e para o desconhecimento da realidade profissional.

O presente estudo objetivou analisar a relação entre a Ciência Geográfica e o exercício profissional da Geografia, tendo como ponto de partida o questionamento sobre a relação existente entre o processo formativo e a práxis profissional. Partindo-se da enunciação de cada uma das três formas regulamentadas de exercício profissional da Geografia no Brasil, procurou-se explicar as especificidades e correlações entre as respectivas categorias profissionais, demonstrando suas áreas de atuação e atividades profissionais, seus desafios formativos e laborais, além das habilidades e competências necessárias às profissões.

Notou-se que o profissional da Geografia é definido, legalmente, com base na modalidade de sua formação científica e nas atividades que desempenhará, para as quais a sua formação deverá prepará-lo.

Observou-se que os três campos de atuação profissional da Geografia são a Área Técnica, a Educação Básica e a Educação Superior, nas quais atuam como profissionais, respectivamente, o Geógrafo, o Professor de Geografia da Educação Básica e o Professor de Geografia do Ensino Superior. Uma vez que o Professor de Geografia do Ensino Superior é o responsável pela formação dos outros dois, acabou-se dando maior ênfase às questões relacionadas ao Geógrafo e ao Professor de Geografia da Educação Básica, pois, a definição destes é iniciativa fundamental para a ressignificação daquele.

Ao se analisar as práticas e atribuições profissionais do Geógrafo e do Professor de Geografia da Educação Básica, concluiu-se que as dicotomias, subdivisões e especializações da Geografia não correspondem às realidades laborais da Área Técnica e da Educação Básica.

Dentre os resultados apresentados pelo estudo estão: um quadro comparativo das categorias profissionais da Geografia no Brasil e, por fim, uma seção onde são apresentadas propostas para a superação dos desafios formativos e laborais da Geografia no Brasil.

Acredita-se que o presente estudo traz potencial contribuição para a elucidação de dúvidas quanto ao exercício profissional da Geografia, dúvidas essas que acompanham tanto graduandos quanto egressos e até mesmo pós-graduandos em Geografia. 


\section{REFERÊNCIAS}

ANDRADE, M. C. de. Geografia: ciência da sociedade. 2a ed. Recife: EDUFPE, 2008. 246 p.

ANDRADE, M. C. de. Perspectivas do papel do geógrafo, como profissional, no Brasil. Boletim de Geografia Teorética, Rio Claro, v. 16/17, n. 31-34, p. 409-422, 1986/1987.

AZEVEDO, T. R. de. O destino dos egressos de cursos de geografia. In: ENCONTRO DE GEÓGRAFOS DA AMÉRICA LATINA, 9. 2005, São Paulo. Anais. São Paulo: Universidade de São Paulo, 2005, p. 1355-1375.

BONFIGLIO, R. A importância da empresa júnior na formação do profissional de geografia. 2006. 114f. Monografia (Trabalho de Graduação em Geografia) - Centro de Ciências Exatas, Universidade Estadual de Londrina, Londrina, 2006.

BRASIL. Lei $\mathrm{n}^{\circ}$ 6.664, de 26 de junho de 1979. Disciplina a profissão de Geógrafo e dá outras providências. Diário Oficial da União da República Federativa do Brasil, Brasília, DF, 27 jun 1979.

BRASIL. Decreto $n^{\circ} 85.138$, de 15 de setembro de 1980. Regulamenta a Lei $n^{\circ} 6.664$, de 26 de junho de 1979, que disciplina a profissão de Geógrafo, e dá outras providências. Diário Oficial da União da República Federativa do Brasil, Brasília, DF, 17 set 1980.

BRASIL. Lei $n^{\circ} 7.399$, de 04 de novembro de 1985. Altera a redação da Lei $n^{\circ} 6.664$, de 26 de junho de 1979, que disciplina a profissão de Geógrafo. Diário Oficial da União da República Federativa do Brasil, Brasília, DF, 05 nov 1985.

BRASIL. Decreto $n^{\circ}$ 92.290, de 10 de janeiro de 1986. Regulamenta a Lei $n^{\circ} 7.399$, de 04 de Nov 1985, que altera a redação da Lei $\mathrm{n}^{\circ}$ 6.664, de 26 jun 1979, que disciplina a profissão de Geógrafo.

Diário Oficial da União da República Federativa do Brasil, Brasília, DF, 13 de jan. 1986.

BRASIL. Lei n ${ }^{\circ}$ 9.394, de 20 de dezembro de 1996. Estabelece as diretrizes e bases da educação nacional. Diário Oficial da União da República Federativa do Brasil, Brasília, DF, 23 dez 1996

BRASIL. Ministério da Educação. Conselho Nacional de Educação. Parecer CNE/CES 492/2001. Trata das Diretrizes Curriculares Nacionais dos cursos de Filosofia, Historia, Geografia, Serviço Social, Ciências Sociais, Letras, Biblioteconomia, Arquivologia e Museologia. Diário Oficial da União da República Federativa do Brasil, Brasília, 9 jul 2001.

BRASIL. Ministério da Educação. Portaria N ${ }^{\circ} 1.570$, de 20 de dezembro de 2017. Diário Oficial da União da República Federativa do Brasil, Brasília, 21 dez 2017, Seção I, p. 146.

BRASIL. Ministério da Educação. Base Nacional Comum Curricular: educação é a base. Brasília, 2018. Disponível em: http://basenacionalcomum.mec.gov.br/images/BNCC EI EF 110518 versao final_site.pdf. Acesso em 31 ago 2021.

BRASIL. Conselho Nacional de Educação. Resolução CNE/CES 14/2002. Estabelece as Diretrizes Curriculares para os cursos de Geografia. Diário Oficial da União da República Federativa do Brasil, Brasília, 9 abr 2002.

BRASIL. Ministério do Trabalho e Emprego. Classificação Brasileira de Ocupações - CBO.

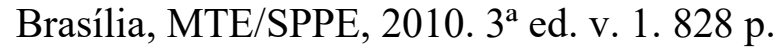


BROGGIO, C.; PHLIPPONNEAU, M. La geografía profesional en Francia: del geógrafo universitario al geógrafo profesional. Documents d'Anàlisi Geogràfica, Barcelona, v.39, [s.n], p. 97-117, 2001.

HEIDRICH, Á. L.; VERDUM, R. Estágio profissional em geografia pela UFRGS. Boletim Gaúcho de Geografia, Porto Alegre, v. 27, n. 1, p. 166-170, 2001.

LAGE, C. S. Refletindo sobre o projeto de pesquisa em geografia. $1^{\text {a }}$. ed. Salvador: Mestrado em Geografia da Universidade Federal da Bahia, 2002. v. 1. 50p.

LOPES, C. S. A formação e o desenvolvimento da profissionalidade do professor de geografia. Olhar de Professor, Ponta Grossa, v.13, n.1, p.47-66, 2010.

LOPES, L. de A. O geógrafo de papel ou o papel do geógrafo? Algumas considerações sobre a atuação do profissional na sociedade. In: Encontro Baiano de Geografia, 8. 2011, Vitória da Conquista. Anais. Vitória da Conquista: Universidade Estadual do Sudoeste da Bahia, 2011, p. 1-10.

MAGALHÃES, V. B. et al.; RIBEIRO, K. V.; ALBUQUERQUE, E. L. S. Formação em geografia: um olhar para os bacharéis frente às competências e desafios. Geografia: Publicações Avulsas, Teresina, v.2, n. 1, p.211-234, 2020.

MOREIRA, R. O que é geografia. 2a . ed. São Paulo: Brasiliense, 2010. 120p.

OLIVEIRA, F. R. de M. et al.; SILVA, L. C. M. da; BATISTA, C. T.; DINIZ, M. T. M. Empresa Júnior do Laboratório de Geoprocessamento e Geografia Física - EJ LAGGEF. Revista do CERES, v. 1, n. 1, p. 35-39, 2015.

RODRIGUES, A. de J. Geografia: introdução à ciência geográfica. 1 ${ }^{\text {a }}$. ed. São Paulo: Avercamp, 2008, 150p.

ROSA, P. R. et al.; BARROS, M. J. V.; NASCIMENTO, M. O. T.; ROSA, C. R.; ALONSO, S. F.; GALVAO, S. M.; MORAIS, A. C. F.; ROSA, P. R. O. Mercado potencial de trabalho para o Geógrafo na Grande João Pessoa. In: CONGRESSO BRASILEIRO DE GEÓGRAFOS, 6. 2004, Goiânia. Setenta anos da AGB: as transformações do espaço e da Geografia no século XXI, 2004.

SAMPAIO, T. V. M. et al.; PELEGRINA, M. A.; SOPCHAKI, H. S. Exercício profissional do geógrafo no Estado do Paraná: convergências e divergências entre a Lei do Geógrafo, as Diretrizes Curriculares Nacionais, as matrizes curriculares e a prática profissional. Ra'e Ga, Curitiba, v.42, p. $269-287,2017$.

SANTOS, R. A. dos. Formação profissional em geografia: a graduação no Campus Catalão/UFG e os Projetos Pedagógicos de 1992, 2005 e 2009. 2013. 131f. Dissertação (Mestrado em Geografia) - Programa de Pós-Graduação em Geografia, Universidade Federal de Goiás, Catalão, 2013.

SAUER, C. O. A educação de um geógrafo. Geographia, Niterói, v. 2, n. 4, p. 137-150, 2000.

SEEMANN, J. Geógrafos e geografias - contribuições para a discussão sobre a (não) importância da geografia. Revista da Casa da Geografia de Sobral, Sobral, v. 2, n. 1, p. 87-95, 2000.

SILVA, A. C. O que é o Geógrafo profissional? Revista do Departamento de Geografia, São Paulo, v. 2, p. 81-92, 1983.

SILVA, J. L. B.; RAMIRES, R. R. Formações em geografia - identidades e articulações. Boletim Paulista de Geografia. São Paulo, n. 86, p. 123-135, 2007. 
SILVA, J. L. B.; RAMIRES, R. R. Onde se constrói a identidade formativa do geógrafo e do professor de geografia? Ou ainda, é possível fazer geografia nos cursos de geografia? Terra Livre, Dourados, v. 2, n. 31, p. 173-179, 2008.

TRIGAL, L. L. et al.; FERNANDES, J. A. R.; SPOSITO, E. S.; FIGHERA, D. T. Diccionario de geografía aplicada y profesional: terminología de análisis, planificación y gestión del territorio. León: Universidad de León, 2015.

VERDUM, R. Estágio profissional: formação, prática e reconhecimento. In: COLÓQUIO INTERNACIONAL DE GEOCRÍTICA, 9. 2007, Porto Alegre. Anais. Porto Alegre: Departamento de Geografia/IG/UFRGS, 2007. p. 01-12.

Trabalho enviado em 13/10/2021

Trabalho aceito em 28/11/2021 